\title{
Love as radical politics ${ }^{1}$
}

\section{Abstract}

With the "affective turn" in social studies, the discussion of the role of emotions in social and political life is increasingly becoming a valid topic of inquiry. However, it is the "negative" emotions, like fear, anger, shame, that tend to dominate the discussions, with less attention being given to discussions of hope, compassion, and love. Srecko Horvat's The radicality of love is an attempt to correct this bias. His text makes a case for the social importance of love in the reinvention of revolutionary politics. He does this through a discussion of some of the revolutions of the twentieth century, as well as some of the (revolutionary) social movements of the twenty first century.

Is it possible to characterise a society in emotional terms? And if this is possible, is this a useful thing to do? What does it mean to call a society anxious, angry, or caring? Emotions tend to be associated with the realm of the personal, of the individual, and less so the social. But why this separation? Many years ago Eli Zaresky (1976: 31) writing about the family under capitalism, noted that "... psychology and psychoanalysis distort our understanding of personal life by assuming that it is governed by its own internal laws (for example, the psychosexual dynamics of the family, the 'laws' of the mind or of 'interpersonal relations') rather than by the 'laws' that govern society as a whole". So, different "laws" for personal life, and another set of "laws" for society! Bourgeois thought has tended to be the gatekeeper for the privatisation of personal life, as private property relations came to secure the social relations of the capitalist mode of production, and thus developed a separate episteme for personal, the individual, the emotional, as different and separate from the social.

\section{Grahame Hayes}

University of

KwaZulu-Natal

Durban

\section{Keywords}

emotions, love, revolution, reinventing politics

\footnotetext{
1 A review article of Srecko Horvat (2016) The radicality of love. Cambridge: Polity Press. ISBN 978-0-7456-9115-2 pbk. Pages vii + 174.
} 
However, more recently emotions seem to have been called forth as a useful way of making sense of politics. Many would argue that we can't really understand contemporary social and political developments unless we include the emotional component of human affairs in our analyses (see for instance Ahmed, 2004; Nussbaum, 2013). Crociani-Windland and Hoggett (2012: 163) note that "[i]n some areas of the Social Sciences, this 'affective turn' (Clough, 2007) has been posited as offering a broader alternative to the focus on discourse that has characterised structural analysis; however, in Political Studies the significance of the human passions in political life remains relatively unacknowledged." They point to two main problems with acknowledging the role of emotions in political life (by Political Studies): "First, the view that passion, feeling, affects or emotions as they have been variously spoken of, were essentially ephemeral, that they were a reaction to and/or the consequence of other events, lacking determining force in their own right. Once this objection was gradually overcome and political sociologists and theorists began to see that feelings did play a crucial role in political life, a second difficulty arose. For a variety of reasons there was a studious avoidance of any concept of human emotion that linked it to unreason. (ibid: 163) Amongst the various reasons for an avoidance of emotions in accounting for political life is the rationalist tendency within Political Studies, and thus seeing emotions as irrational, rather than non-rational. If much of what Political Studies is (was) preoccupied with is to do with choice and prediction, then taking emotions into consideration will certainly disrupt conceptions of politics as stable and predictable. Human emotions are not always containable, and people's (political) passions can be wild, unpredictable, and simultaneously both creative and destructive.

And what are some of the emotions that get written about in politics these days? - shame, envy, anger, hate, fear, dread, despair, hope, and love. In an age of Trump, Netanyahu, and many others that we could mention, it is not surprising that much of the political discourse is taken with discussions of anger, rage, violence, and despair, and less so hope and love. Given the ravages of capitalism in many countries it is unremarkable that the focus is on "negative" or destructive emotions. Pankaj Mishra (2016) characterises our age as one of anger, and writes that: "For nearly three decades, the religion of technology and GDP and the crude 19th-century calculus of self-interest have dominated politics and intellectual life. Today, the society of entrepreneurial individuals competing in the rational market reveals unplumbed depths of misery and despair; it spawns a nihilistic rebellion against order itself. With so many of our landmarks in ruins, we can barely see where we are headed, let alone chart a path. But even to get our basic bearings we need, above all, greater precision in matters of the soul. The stunning events of our age of anger, and our perplexity before them, make it imperative that we anchor thought in the sphere of emotions; these upheavals demand nothing less than a radically enlarged understanding of what it means for human beings to pursue the contradictory ideals of freedom, equality and prosperity." (emphases added). What does it mean for our 
political lives to anchor "thought in the sphere emotions"? Surely there are at least two ways of thinking about this, one "negative", and one "positive".

The qualification of "negative" and "positive" is because it seems very difficult to know what is supposedly "normal" with regard to defining a decent and egalitarian social order these days. The negative emotions of despair, rage, and anger, for instance, need to be interrogated, thought, as ways of telling us something about the social and material conditions that give rise to this range of emotions in the first place. In Nussbaum's (2013) view there are three emotions that she thinks create special problems for developing compassionate citizenship, and these are fear, envy, and shame (cf 314-377, chapter 10 of her text). She sees love as a counter to radical evil, and the tendencies in human life that if not checked will wreak havoc on social arrangements. In this regard she writes that the "task for the cultivation of public emotion is to keep at bay forces that lurk in all societies and, ultimately, in all of us: tendencies to protect the fragile self by denigrating and subordinating others. [...] Disgust and envy, the desire to inflict shame upon others - all of these are present in all societies, and, very likely, in every individual human life. Unchecked, they can inflict great damage." (Nussbaum, 2013: 3). Nussbaum's view is that what sustains a decent society are the emotions associated with love. Amongst other media in society she attributes a role to the State in encouraging love and a devotion to ideals of decency, compassion, fairness, and so on. It is hard to think of countries where the current political leaders encourage these kinds of values and responses among the citizenry. For example, South Africa, under Thabo Mbeki's presidency, was meant to be a society based on caring, which seemed not to have made too much progress on this score. The situation is much worse than this, as according to Raymond Suttner "what is new and alarming about many of the ANC's current leaders is their callousness" (Lissoni, 2017). One could hardly read the current bunch of kleptocrats and their looting of public resources as acts of love for the poor!

Fortunately, the positive emotions, of hope, kindness, and love seem dialectically to evoke a counter story to what is wrong with our world, and hopefully prefigure things being different, more equal, more fair, more just, and more compassionate. While many have commented that love is at risk, it is not all doom and gloom (Badiou, 2012; Bongela, 2016; Horvat, 2016; Han, 2017). Nussbaum (2013: 11) reminds us that we at least seem to take care of people that we know, people that somehow matter to us, what she refers to as people within "our circle of concern". The challenge of course for a politics of love is how do we get people who are distant, who are strangers, who are different to us, to be included in our circle of concern. Han (2017: 1) presents the problem much more starkly when he writes that the "crisis of love does not derive from too many others so much as from the erosion of the Other. This erosion is occurring in all spheres of life; its corollary is the mounting narcissification of the Self. In fact, the vanishing of the Other, is

PINS [Psychology in Society] 53 • $2017 \mid 78$ 
a dramatic process - even though, fatefully enough, it largely escapes notice." Following Barthes' (2002: cf 34-36) discussion of the other as atopos, that is, as being unclassifiable, unique, difficult to place, Han (2017: 1-2) suggests that "[t]he Other, whom I desire and who fascinates me, is placeless. He or she is removed from the language of sameness." Han's (2017) "diagnosis" of some of the troubles of contemporary society is around the problem of consumption. Under contemporary capitalism everything is made into something consumable! The motor and logic of this consumption is made possible by the elimination of "otherness in favour of consumable - heterotopic - differences. In contrast to otherness, difference is positive. Yet today, negativity is disappearing everywhere. Everywhere is being flattened out into an object of consumption." (Han, 2017: 2). In this account it is argued that sameness and consumable difference are valorised, which leaves us with a problem in regard to our attitude, and emotional responses, to the Other, to otherness. It is not only psychoanalysis that suggests that the other excites and fascinates us, and yet at the same time unsettles us, and threatens our sense of self, and thus not knowing what do with the other (Other) there is a tendency to retreat, to attack, or to make them the same as us. These kinds of responses to the other are hardly conducive to dealing with refugees, immigrants and foreigners around the world, to that general collection of people who are "not-us".

The general crisis of care and compassion for refugees (in Europe in particular), the upsurge in global xenophobia, the extreme forms of Islamaphobia (especially in the West), and the hate-filled rhetoric of "political movements" (from the BLF to ISIS), might in part account for why recently a range of writers, interestingly mainly philosophers, have tried to present counter stories of the importance of the emotion of love for politics (see amongst others, Ahmed, 2004; Luhmann, 2010; Badiou, 2012; Nussbaum, 2013; Horvat, 2016; Han, 2017). Before I proceed to discuss what some of these "love writers" have to say about love and politics, and especially politics as a form of love, I need to comment on the family of terms being used: feelings, emotion/s, affect. Many writers use these three terms interchangeably, and at the same time there is a sophisticated literature regarding the "affective turn" in social studies that wants to make clear distinctions between feelings, emotions, and affect. For instance, Crociani-Windland and Hoggett (2012: 164) in their article on politics and affect "reserve the term 'affect' to describe the more bodily based and indeterminate level of experience, while using the term 'emotion' to refer to experience that has undergone qualification as it enters into a more discursive level" (emphases added). Be this as it may, there is no agreed on usage or definition of these terms that researchers should adopt. My general, and somewhat loose, usage of the term emotion would have affinity with what Crociani-Windland and Hoggett call "affect"! But, I prefer the term emotion as it has a more everyday feel to it, rather than the more "technical" term of affect, which is not to suggest that I am trying to make or claim some strongly theoretical point, but rather adopting a more convenient 
writerly stance towards love, and love and politics. The appeal of Crociani-Windland and Hoggett's (2012) distinction is that affect includes (emotional) experience that is bodily and indeterminate; and after Foucault and Agamben, how can we not want our politics of love to be a form of biopolitics?

Itis a truism to say that love is difficult to talkaboutbecause itinvolves abodilydimension, and thus how best should we express our feelings of love towards our partners, our children, our collection of jazz music, and the constituency we serve as an elected public official, if words don't quite seem adequate to the task? Luhmann (2010: 4-5) locates the problem as to do with the media of communication, and notes: "Communication, through structured language, acquires the degree of efficiency that enables a person to cope with such a world [an excessively complex and contingent world] and make a great variety of selections within it. In addition to linguistic communication, however, non-linguistic communication exists as an aid to interpreting the spoken word and indeed as an independent means of conveying meaning. It is precisely in matters of love that non-verbal modes of communication are important and indispensable." Luhmann makes a case for actions, as an instance of non-linguistic communication, that would convey the meaning(s) of love, besides the words that one might enunciate to express love.

Whether in small intimate relationships, or in the large public realm of politics, the authenticity of our words of love, are given validation through what we do, through our actions, and through our non-verbal communications. Why do we get embarrassed and tongue-tied when our lover asks us why we love them? In answering this question, we shall say some things, we shall point to the things we do that demonstrate our love, and yet all our evidence-collecting doesn't seem convincing enough. Similarly, if we ask a friend how do they know that their partner / lover loves them, we are not usually bowled over by the elaborate and loquaciousness of their verbal articulations in reply to our question. Again, they will usually say some bumbling things, point to some actions that their lover does as evidence, and often say, "I just know they do". As Horvat (2016:1) notes in the opening sentence of his book: "Each attempt to speak or even write about love is inevitably linked to a profound difficulty, to an anxiety: words are always insufficient." And more poignantly he adds: "However, even if our attempt resembles a jump into dark water, we should dare to talk about love, with all the risks involved. We should try again, fail again, fail better." (ibid).

Many of those writing about love today, bemoan the fact that the discourse on love has become highly individualised ("falling in love"), focused on the private sphere of romantic love, and according to Han (2017: 12) "positivized into sexuality" where the stress is on performance and "consuming" the other. Consequently, the task is to 
recover the social dimensions of love, for love to become a valid public emotion, and thus following Rimbaud, "love has to be reinvented, that's certain" (in Horvat, 2016: 23). Bongela (2016) talks about love being "a skill that is lost to many of us", and wonders what it would "mean to fight for a love ethic in difficult times". In this sense it does seem that love does need to be reinvented, and that we need to be taught love as a social skill, or rather taught how to love socially.

Luhmann (2010: 17) suggests that the sociality of love is paramount for the proper functioning of society, and writes that, "[w]hile it may be entirely conceivable to lead a life individually without love and yet find self-affirmation in the world (for example through one's achievements or successes), it is not at all possible for love to be replaced as a mechanism of society as a whole". This statement is all the more remarkable given the loveless state of contemporary political discourse. In fact, contemporary political discourse seems hate-filled, belligerent and threatening much of the time, and yet we are supposedly in a post-Cold War era. How might expressions of love operate in politics, and what would it mean for this to be the case? It is not that we want politicians to go around telling us that they love us, and even if they did we wouldn't easily believe them given the barrage of mendacious propaganda that characterises much of contemporary politics. And yet is it not worth imagining a politics founded on the radicality of love, both in its discourse and its varied practices? Some of these practices would entail risk and the opening up of public democratic spaces for debate and participation, which would run counter to the top-down, rationalist, and technocratic form of politics currently on offer in many countries.

For instance, Luhmann (2010: 9) argues that "[s]ocial systems which are structured according to love impose on themselves a requirement of communicative openness for topics that have not been fixed in advance. They thus leave themselves open to considerable risk" (emphases added). Very few public representatives want to risk being told what to do by the ordinary masses of people they supposedly represent and are meant to serve. How often do politicians, even during electioneering, listen to, or pretend to listen to, what people want or are concerned about? These forms of openness are too risky and not easily able to be controlled, and hence are not encouraged. The issue of control for politics is complicated, as too much control is obviously repressive and curtailing of the free expression of ideas, and yet too little control poses difficulties for governing and social cohesion. However, Badiou (2012: 71-72) suggests that the "problem politics confronts is the control of hatred, not of love. And hatred is a passion that almost inevitably poses the question of the enemy. In other words, in politics, where enemies do exist, one role of the organization, whatever that may be, is to control, indeed to destroy, the consequences of hatred. That doesn't mean it must 'preach love', but a major intellectual challenge it faces is to 
provide the most limited, precise definition possible of the political enemy. And not, as was the case throughout almost the whole of the last century, the vaguest, most far-reaching definition imaginable".

There are a range of complex issues to unpack here. Politics should control hatred, but many countries seem to falter on this. Hatred is not some abstraction, but manifests itself as racist and hurtful name-calling; the desecration of synagogues; the assassination of political opponents; the brutal ("corrective") rape, and often murder, of lesbian women; and on and on, unfortunately. The question to be asked is why so many countries falter at containing and controlling these forms of violent hatred. Bizarrely, as Ahmed (2004: cf 122) points out, it is even "hate groups", like some of the white right groups in the USA, that "declare themselves as acting out of love". They suggest that they are acting out of love for their own group, and are not against others.

Interestingly, Horvat (2016) directs much of his attention at how revolutionary movements, and nascent left-wing governments came to control love (and desire), and less so hatred. Horvat wants to bring love and revolution into a close dialectical tension, and suggests that for a revolution to be worthy of the name it should also entail a reinvention of love. He does this by taking an historical stroll through the revolutions and revolutionary movements of the twentieth and early twenty first century asking "seemingly naïve questions on love, sex, and revolution" (Horvat, 2016: 20). Expanding on this Horvat (2016: 20-21) writes: "It is as if, from the 'Arab Spring' to the 'Occupy Movement', from São Paulo to Hong Kong, from Athens to Sarajevo, there is no consciousness that we can never really imagine a different and better world without the reinvention of love. The reinvention of the world without the reinvention of love is not a reinvention at all. And this is the reason why all important revolutions of the twentieth century - from the October Revolution to the Iranian Revolution - aimed at regulating the most intimate spheres of human life."

In discussing the October Revolution (chapter 3 ) Horvat points to the significant changes that were made regarding property rights, religion, women's rights, and the changes dealing with marriage and children. There were also discussions and debates about "free love", and concerns of bourgeois sexual morality. However, the opening up of the discussions and practices surrounding love, desire, and sexuality didn't last very long as these "love matters" were considered to be detractions from the necessary discipline required of the new Soviet citizen! During the 1920s in the Soviet Union a certain Dr Lemberg recommended "rules" for avoiding sexual stimulation on the grounds that "[s] exual energy is ... conceived as a working class resource that should be preserved for the sake of proletarian creativity and production (even 'flirtation, courtship, coquetry and other methods of specifically sexual conquest' should be avoided." (Horvat, 2016: 86-87). 
These views weren't from some crackpot advisors, but increasingly official Soviet views about the need not to waste energy on libidinal investments when all resources were needed to build the new socialist society. Retarding the sexual revolution was seen as in the interest of building the "new man" (person) of the Soviet Union, and advancing the class struggle in consolidating the proletarian revolution. While Lenin, in his discussions with Inessa Armand and Clara Zetkin, thought that "free love" was a bourgeois concept and not a proletarian one, he was not advocating a form of physical asceticism, but rather wanting to emphasise the important objective, class relations that still needed to be attended to. So, in essence, the revolution of the social relations of production first, and then we'll attend to the revolution of the human side of desire and love.

The social whole cannot be conceived of in this way, nor does social life operate in this way, and so there are bound to be problems in separating out the social / political, and the personal / emotional. Suspending the emotional and intimate aspects of human life from the other aspects of revolutionary transformation does not mean that "nothing happens" to Love while it waits for the objective conditions of the revolution to be secured! Horvat (2016: 102) argues that "[e]ven at the very beginning of every revolution, or upheaval, or protest, or occupation, you must deal with the 'human factor' (to organize things, channel energy, etc); you can't ignore desires or libidinal investments". This was precisely the type of argument that Wilhelm Reich (1972) was making in trying to get European communist parties, and the Soviet Union to accept the importance of not suppressing the sexual revolution. Reich was concerned about the societal consequences of inhibiting sexual expression in a repressive and conservative way.

Suppressing Love, even momentarily in the revolution, worries Horvat who considers the possible consequences of the stalling of the "human factor". For Horvat (2016: 103) this "raises a number of truly traumatic questions: how does Revolution, that is Love, turn into love of Terror, into terror as love?; how does the need to protect your child transform into violence worthy of every beast that protects its cub?; how does 'freedom of love' turn into a nightmare of trying to possess the Other?; how does an openness to a New World sink into the lowest of human passions of assimilating, closure?" He tries to address these complex and urgent questions by discussing the contradictory situation that Che Guevara often found himself in (Chapter 4: The temptation of Che Guevara - Love or revolution).

The Left tend to remember Che Guevara's comment that "the true revolutionary is guided by great feelings of love ... [and] ... vanguard revolutionaries must idealize this love of the people, of the most sacred causes, and make it one and indivisible" (Guevara, in Horvat, 2016: 109 - emphases added). The Right, however, tend to remember Guevara saying: "hatred as an element of the struggle, a relentless hatred of the enemy, impelling 
us over and beyond the natural limitations that man is heir to and transforming into an effective, violent, selective, and cold killing machine. Our soldiers must be thus; a people without hatred cannot vanquish a brutal enemy". (Guevara, in Horvat, 2016: 108 - emphases added). Is this a case of hating the enemy, the Other, and loving the (our) people, those that we identify as like us, the Same, not-Other? Horvat suggest so, but not as an either / or, and rather as an and / or. There is a dilemma and a contradiction here, but one doesn't need to appeal to psychoanalysis, to see how close love and hate are, both in our social and political lives, and in our personal and intimate lives. We don't usually go around hating anonymous strangers, but tend to hate people we love, or have loved, and / or people who can hurt us, because maybe they are close to us in some way, like our enemies. It seems obvious that without some hatred towards (and passion against) our enemies, we won't really be successful at vanquishing them. At least two issues present themselves here. Firstly, we can distinguish between the enemy being a person, a people, and the more abstract notion of the enemy being a system: capitalism, and class exploitation; apartheid, and other forms of racial oppression; patriarchy; and so on. We can also express hatred towards certain features of social life: greed; selfishness; cruelty; and so on. This is not to deny that we do express hatred towards people, but it is practically and theoretically possible to distinguish between a human person, and some of the reprehensible values and ideals that a person (a people) might espouse or represent. Secondly, the greater challenge seems to be whether we can come to love our enemies once the fight is over! The work that would be involved here would require both moral and political considerations to be taken into account to safeguard the fragile social relations of any emerging new society. In some sense this is what the Truth and Reconciliation Commission tried to do. There were many successes of the TRC, as well as criticisms, but maybe one of its biggest failings was not to include more ordinary people in the project of reconciliation, and the building of a future society based on justice, respect and dignity.

The critical question, following Touraine (2000), is: how can we live together? What kinds of structures, public spaces, practices and conversations need to be set up so that "former enemies" can come to live together, and hopefully start to prefigure a society based on love? Touraine (2000: 263) suggests that in "our societies, integration cannot be achieved by introducing stricter rules and greater conformism. It can only be achieved by displacing the goal of integration from the system to the actor, and from society to the individual". Further, he elaborates, saying the "words and the life of every individual must be central to collective life; before he or she becomes a citizen who takes part in the life of the state or a worker who plays economic role, the individual must be a personal Subject who can construct an individuated life" (ibid). Touraine is not trying to advocate a highly individualised form of social and political action, but instead is arguing for an active role for the individual, as an 
individual among other individuals, for the individual as part of a collective, and for the individual as a Subject (of a social movement). On the Subject Touraine (2000: 13) writes: "I call the individual's attempt to become an actor 'the Subject' ... [and] ... The Subject has no content but its own production". In a revolutionary context the Subject must become the individual who acts for Love, and not hate.

Like Touraine's (active) Subject, Horvat also wants a social role for Love. Of course love has to do with two people in an intimate interpersonal relationship, and Horvat says much about these relationships, but his interest is in arguing for the radicality of love in the social sphere. For Horvat (2016: 118) the "radicality of love does not consist, as it is routinely considered, in the exclusive orientation of one being toward the other: in the fatal erasing of the rest of the world. Love for only one person is a piece of barbarism ... for it is practiced at the expense of all others". Horvat contrasts the interpersonal dimension of love (small I) as "falling in love", with the social and outward, towards others and the Other, as Love (capital L). Horvat (2016: 152) writes that "if we really want to understand the difference between falling in love and Love: the demand for the exclusivity of a human being is a characteristic of falling in love, whereas Love is the pure opposite. It is not radical to circle around the other like a dead star and absord him [or her] into a black light. This would be what Michael Hardt calls 'love of the same', a unification through erasing differences. It is a narcissistic form of love."

What Horvat doesn't say enough about is how we might become the Subjects for Love in our societies. However, what he is clear about is that our politics, and in particular revolutionary politics, needs more love, and Love, if we are to reinvent what it means to live in a different world. Unless we are prepared to imagine some utopian possibilities we might just remain stuck in the exploitative and oppressive present. Horvat, fortunately, to my way of thinking, is prepared to allow himself to think about the radicality of love in relation to imagining a different world. He suggests that "[w]hat is needed, in order to achieve a truly radical revolution, is love. Because love is, as Alain Badiou puts it, a form of 'minimal communism'. ... But love is as difficult as communism, and can often end up as tragic as communism. Like revolution, true love is the creation of a new world." (Horvat, 2016: 119) In imagining and trying to create a new world, maybe we could do worse that to think of how love could be a part of radical political practices.

\section{References}

Ahmed, S (2004) The cultural politics of emotion. Edinburgh: Edinburgh University Press. 
Badiou, A (2012) In praise of love. London: Serpent's Tail (French-2009).

Barthes, R (2002) A lover's discourse: Fragments. London: Vintage (French-1977).

Bongela, M (2016) How do we fight for a better love ethic anyway? Mail \& Guardian (Friday), 11-17 November 2016, p 2.

Crociani-Windland, L \& Hoggett, P (2012) Politics and affect. Subjectivities, 5, 161-179.

Han, B-C (2017) The agony of eros. Cambridge, MA: MIT Press (German-2012).

Horvat, S (2016) The radicality of love. Cambridge: Polity Press.

Lissoni, A (2017) Remembering South African struggle hero Chris Hani: Lessons for today. The conversation, 9 April 2017. Accessed: 11 April 2017. https://theconversation. com/remembering-south-african-struggle-hero-chris-hani-lessons-for-today-64715

Luhmann, N (2010) Love: A sketch. Cambridge: Polity Press (German-2008).

Mishra, P (2016) Welcome to the age of anger: The seismic events of 2016 have revealed a world in chaos - and one that old ideas of liberal rationalism can no longer explain.

Guardian, “The Long read", 8 December 2016. Accessed: 10 December 2016. https:// www.theguardian.com/politics/2016/dec/08/welcome-age-anger-brexit-trump

Nussbaum, M (2013) Political emotions: Why love matters for justice. Cambridge, Ma: The Belknap Press.

Reich, W (1972) The sexual revolution: Toward a self-governing character structure. London: Vision Press (German-1936).

Touraine, A (2000) Can we live together? Equality and difference. Cambridge: Polity Press (French-1997).

Zaretsky, E (1976) Capitalism, the family and personal life. London: Pluto Press. 